\title{
ARMED REVOLT IN MOSCOW IN DECEMBER, 1905 IN THE MIRROR OF ORIGINAL RUSSIAN PAREMIOLOGY ADAPTATION
}

\author{
Artur V. Zagrebelnyy \\ Vologda Research Center of the Russian Academy of Sciences, Vologda, Russia
}

\begin{abstract}
The purpose of the article is to display some results of linguistic analysis of proverb adaptation motivated by the armed revolt in Moscow in December, 1905. The novelty of the research is that the adapted proverbs Moscow is not beautiful for its houses, but it is beautiful for its blood traces and Moscow brings no damage to Dubasov were chosen for the first time as objects of analysis in historical and cultural aspects by the method of historically distanced adapted proverb analysis, developed and approved by the author. The research method comprises elements of componential, contextual, logical and semiotic analysis along with the dictionary definition interpretations. The article states the following results: original proverbal sources for cultural transformation may be stated as identification potential of the adapted proverbs by establishing a prototypical comparison system based on structural model similarity and assigning both adapted and proverbal phrases in Russian to one of the four highest logical and semiotic invariant groups; the method of historically distanced adapted proverb analysis contributes to defining extralinguistic factors which caused formation of new language units; the judgments expressed by the adapted proverbs under studies were formulated; the types of adapted proverbs were singled out. The further studies of adapted paremiology motivated by social and political events in 1905-1907 Russia might be considered as research prospects with compliancy of adapted paremiology dictionary for the period of the first Russian revolution. proverb.

Key words: paremiology, adapted proverb, structural paremiology, structural source proverb, proverb, anti-

Citation. Zagrebelnyy A.V. Armed Revolt in Moscow in December, 1905 in the Mirror of Original Russian Paremiology Adaptation. Vestnik Volgogradskogo gosudarstvennogo universiteta. Seriya 2. Yazykoznanie [Science Journal of Volgograd State University. Linguistics], 2020, vol. 19, no. 5, pp. 87-98. (in Russian). DOI: https://doi.org/10.15688/jvolsu2.2020.5.8

\section{ДЕКАБРЬСКОЕ ВООРУЖЕННОЕ ВОССТАНИЕ В МОСКВЕ В 1905 Г. В ЗЕРКАЛЕ АВТОРСКОЙ ПАРЕМИОЛОГИИ РУССКОГО ЯЗЫКА}

\author{
Артур Владимирович Загребельный \\ Вологодский научный центр РАН, г. Вологда, Россия
}

\begin{abstract}
Аннотация. Цель статьи заключается в изучении авторских паремий, мотивирующим событием для образования которых стало вооруженное восстание в Москве в декабре 1905 г., в лингвистическом, логикосемиотическом и культурно-историческом аспектах. Новизна исследования состоит в том, что в научный оборот вводятся авторские паремии Не красна Москва домами, а кровавыми следами и Быль молодиу не укор, « а Москва Дубасову не убыток, а также в том, что они описаны в соответствии с разработанной и апробированной автором статьи методикой анализа исторически дистанцированных авторских паремий русского языка. В результате проведенного исследования установлены паремии - источники трансформации; научно обоснована узнаваемость в рассмотренных авторских паремиях их системных прототипов путем установления общڤ. ности их структурных моделей, определения принадлежности паремий-источников и авторских паремий к ल̈ одной из четырех высших логико-семиотических инвариантных групп; проанализированы факторы внешней () среды, обусловившие появление новых языковых единиц; сформулированы суждения, выражаемые рассмот-
\end{abstract}




\section{РАЗВИТИЕ И ФУНКЦИОНИРОВАНИЕ РУССКОГО ЯЗЫКА}

ренными авторскими паремиями; определены типы авторских паремий. В качестве перспектив исследования отмечены дальнейшее изучение авторской паремиологии русского языка периода 1905-1907 гг, систематизация авторских паремий в зависимости от мотивировавших их образование событий общественно-политической жизни страны, создание словаря авторской паремиологии периода первой русской революции.

Ключевые слова: паремия, авторская паремия, структурная паремиология, паремия-источник, пословица, антипословица.

Цитирование. Загребельный А. В. Декабрьское вооруженное восстание в Москве в 1905 г. в зеркале авторской паремиологии русского языка // Вестник Волгоградского государственного университета. Серия 2, Языкознание. - 2020. - Т. 19, № 5. - C. 87-98. - DOI: https://doi.org/10.15688/jvolsu2.2020.5.8

\section{Введение}

Авторская паремиология современного русского языка в настоящее время активно исследуется учеными [Антонова, 2011; Батулина, 2003; Бегун, 2010; Буренкова, 2008; Бутько, 2008; Вальтер, Мокиенко, 2005; Гнедаш, 2005; Демидкина, 2017; Дидковская, Петрова, 2014; Жигарина, 2006; Зайкина, 2018; Кирсанова, 2014; Константинова, 2009; Никитина, 2014; Савенкова, 2014; Соловьева, 2011; Сташкова, 2015; Швыдкая, 2011; и др.]. Столь пристальное внимание к данному языковому материалу вполне объяснимо: получаемые в ходе анализа результаты позволяют, как мы уже писали, «установить и классифицировать сами механизмы преобразований; определить роль широкого экстралингвистического контекста и непосредственного языкового окружения в формировании выражаемых ими суждений, что важно не только для самой паремиологии, но и для дальнейшего изучения проблемы взаимообусловленности развития языка и социума; отследить динамику изменений в культурно-духовной сфере жизни общества и его ценностной картине мира, отражающуюся в зеркале новой трансформированной паремиологии; изучить вопрос об их статусе, что даст ученым еще одну возможность взглянуть на фундаментальную проблему соотношения языка и речи под новым углом; углубить наши знания об использовании приемов языковой игры в процессах их создания» [Загребельный, 2018]. Однако исследования в области исторической авторской паремиологии все еще остаются немногочисленными (см.: [Загребельный, 2018; 2019а; 2019б; и др.]).

Первая русская революция 1905-1907 гг. в Российской империи была перенасыщена разнообразными событиями общественнополитической жизни. Напряженная обще- ственно-политическая борьба, как было показано нами ранее, не только «актуализировала и утвердила в тезаурусе наименования политических партий и их представителей, наименования новых демократических прав и свобод человека в России, названия представительных органов власти, названия системы выборов власти в государстве и др.» [Загребельный, 2013, с. 4], но и обусловила изменения в других системах и подсистемах языка. Так, авторы журналов общественно-политической сатиры стали активно создавать трансформированные (авторские) паремии на базе уже существовавших в языке пословиц, поговорок и пословично-поговорочных выражений. Как показала О.Н. Антонова, цель, которую они преследовали, была достаточно проста: привлечь внимание общественности к тем или иным событиям, поступкам политических деятелей [Антонова, 2011, с. 5].

Одним из самых резонансных событий 1905 г. было декабрьское вооруженное восстание в Москве. Небывалая жестокость, с которой правительство подавило это восстание, не могла не мотивировать создание авторских паремий. На страницах общественнополитических сатирических журналов в 1906 г. появились «новые пословицы», выражавшие через измененные классические паремии резко негативное отношение их авторов как в целом к произошедшему событию и его ужасным последствиям, так и к руководившему подавлением восстания московскому генерал-губернатору, адмиралу Ф.В. Дубасову.

Цель нашей работы заключается в исследовании авторских паремий русского языка периода первой русской революции, мотивирующим событием для образования которых послужило декабрьское вооруженное восстание в Москве в 1905 г., в лингвистическом, 
логико-семиотическом и культурно-историческом аспектах.

\section{Материал и методика исследования}

Нами выявлены три языковые единицы, мотивированные событиями московского декабрьского восстания 1905 г.: Не красна Москва домами, а кровавыми следами, Быль молодиу не укор, а Москва Дубасову не убыток и Бей, адмирал, наместником будешь. В статье мы остановимся на анализе первых двух. Изучение обнаруженных авторских паремий проведено с использованием разработанной нами методики [Загребельный, 2019а, с. 198-199], в соответствии с которой устанавливается паремия-источник; определяется принадлежность паремииисточника и образованной на ее основе авторской паремии к одной из четырех высших логико-семиотических инвариантных групп (об их выделении и о методе логико-семиотического анализа подробно написано в трудах Г.Л. Пермякова [Пермяков, 1970; 1979; 1988]); устанавливается механизм образования новой языковой единицы; определяются значения слов компонентов авторской паремии, приводится сумма этих значений; устанавливаются факты общественно-политической жизни страны, которые привели к образованию исследуемой языковой единицы; формулируется выражаемое авторской паремией суждение; определяется тип авторской паремии (пословица, поговорка, пословично-поговорочное выражение) [Загребельный, 2019а, с. 199].

В рамках указанной методики используются методы компонентного контекстуального и логико-семиотического анализа, анализа словарных дефиниций.

\section{Результаты и обсуждение}

Авторская паремия Не красна Москва домами, а кровавыми следами (Зарницы, c. 7) образована на базе паремии-источника Не красна изба углами, а красна пирогами, выражающей следующее суждение 'Дом хорош не внешним видом, убранством, а хлебосольством, гостеприимством хозяев' (СРП, с. 129). Тип паремии-источника пословично-поговорочное выражение (сло- во изба является первично маркированным).

Образование новой языковой единицы стало результатом структурной трансформации паремии-источника, состоящая в замене слов-компонентов изба углами на Москва домами и красна пирогами на кровавыми следами.

В основу исследуемой авторской паремии положена типическая ситуация, при которой наличие у одной вещи (P1) какого-либо одного свойства (x1), а у другой вещи (P2) другого свойства или другой степени его проявления (х2) предполагает, что одна из вещей предпочтительнее другой [Пермяков, 1979, с. 50]. Под Р1 и Р2 понимается Москва (Р2 не объективирована словом-компонентом, но подразумевается), под свойством х1 - красна домами, под свойством х2 красна кровавыми следами. Москва, которая красна кровавыми следами, предпочтительнее (исходя из содержания авторской паремии) Москвы, которая красна домами. Следовательно, анализируемая авторская паремия входит в состав высшей логикосемиотической инвариантной группы II (2). Паремия-источник трансформации входит в состав той же высшей логико-семиотической инвариантной группы.

Узнаваемости в авторской паремии Не красна Москва домами, а кровавыми следами ее системного прототипа наравне с общностью отнесения к одной и той же высшей логико-семиотической инвариантной группе, сходством структурных моделей способствует и их вхождение в одну и ту же логикотематическую группу «Красивый - уродливый» (здесь и далее названия групп указаны по: [Пермяков, 1979, с. 42]).

Рассмотрим компонентный состав исследуемой языковой единицы. Отрицательная частица не употреблена вместе с союзом $a$ в конструкции противопоставления; эта частица '1. Вносит знач. полного отрицания того, что обозначает слово или словосочетание, перед которым оно стоит' (НБАС, т. 11, с. 498). Прилагательное красныци, представленное в краткой форме в женском роде и в ед. ч., имеет значение '3. Устар. и нар.-поэт. Красивый, прекрасный (обычно как постоянный эпитет)' (НБАС, т. 8, с. 592). Существительное Моск- 
ва является именем собственным, называющим столицу российского государства. Существительное дом, использованное в форме твор. п. мн. ч., определяется как '1. Здание, строение, предназначенное для жилья, для размещения учреждений и предприятий' (НБАС, т. 5, с. 245). Союз а употреблен в противительном значении: ' 1 . Употребляется для соединения противопоставляемых предложений или отдельных членов предложения; соответствует по значению словам: но, зато, наоборот, напротив' (МАС, т. 1, с. 17). Прилагательное кровавый, использованное в форме твор. п. мн. ч., толкуется следующим образом: '1. Покрытый, залитый кровью, окровавленный' (НБАС, т. 8, с. 652). Существительное след в форме твор. п. мн. ч. означает '2. Углубление, знак, метка на чем-либо от прикосновения, надавливания, царапания и т. п.' (БАС, т. 13, с. 1167).

Сумма значений слов-компонентов анализируемой авторской паремии может быть представлена в следующем виде: 'Москва красива не своими зданиями, а залитыми кровью отметками'. Как видим, данная сумма значений не составляет выражаемого исследуемой языковой единицей суждения, следовательно, перед нами либо пословица, либо пословично-поговорочное выражение.

Обратимся к экстралингвистическим факторам, обусловившим появление рассматриваемой авторской паремии.

Наиболее масштабным событием всей первой русской революции 1905-1907 гг., произошедшим в Москве, несомненно, было декабрьское вооруженное восстание, в ходе которого погибли тысячи человек: «Трепов уверяет, что в Москве перебито до 10000 революционеров, несомненно вздор. Много тысячи две. Ведь собственно боя открытого нет. Стреляют из-за засад, из окон и убегают» (Киреев, с. 116).

В начале активных боевых действий в Москве революционерам противостояли 1350 солдат московского гарнизона, что позволяло «удерживать только положение, занятое в центре города, оставляя все станции железных дорог и все окраины города открытыми» (Революция 1905 года, с. 186). Кардинально ситуация изменилась после прихода в город Семеновского и Ладожского полков об- щей численностью 1200 человек (Революция 1905 года, с. 186). В итоге восстание было жестоко подавлено. В опубликованных воспоминаниях современники тех событий А.А. Пиленко и Л.А. Тихомиров назвали все происходившее в Москве в декабре 1905 г. страшной резней (Стенографический отчет, с. 94) и светопреставлением (Тихомиров, с. 172).

Использование артиллерии в совокупности с неизбирательным применением силы привело к многочисленным жертвам среди мирного населения. Достоверных сведений о количестве убитых и раненых граждан, не принимавших участия в вооруженном восстании, на сегодняшний день не существует. Тем не менее о масштабах катастрофы можно судить уже по тому, что организатор подавления восстания московский генерал-губернатор Ф.В. Дубасов в своем донесении от 19 декабря 1905 г. на имя императора Николая II отметил страшные последствия применения регулярных частей армии в Москве и просил оказать поддержку всем пострадавшим: «Всеподданнейше доношу вашему императорскому величеству, что при действиях войск против мятежников неизбежно пострадало мирное верноподданное население столицы, потерявшее убитыми и ранеными членов семей - мужчин, женщин и даже детей, а также оставшееся без крова вследствие уничтожения или повреждения многих жилищ артиллерийским огнем. <..> Осмеливаюсь поэтому усердно просить ваше императорское величество повелеть мне объявить обывателям Москвы, что правительство придет теперь же на помощь пострадавшим и облегчит их тяжелое положение в форме и размере, какие благоугодно будет вашему императорскому величеству указать» (Революция 1905 года, c. 181).

В результате подавления вооруженного восстания Москва в декабре 1905 г. в действительности была покрыта кровавыми следами. Именно такой запомнилась столица Российской империи очевидцам тех событий. Например, известный революционер-большевик В.И. Невский в работе «Советы и вооруженное восстание в 1905 году» писал следующее: «Хорошо было министру внутренних дел, сидя у себя в кабинете и зная, что семеновцы залили кровью рабочее восстание в Москве, 
благодушно успокаивать царя, но каково было чувствовать себя Воронцову-Дашкову, у которого командиров роты повстанцы стреляли, как куропаток. Было от чего переутомиться!» (Невский, с. 243).

Приведенные экстралингвистические факты позволяют однозначно определить декабрьское вооруженное восстание в Москве в 1905 г. в качестве события, положенного в основу образования авторской паремии Не красна Москва домами, а кровавыми следами.

Для того чтобы сформулировать выражаемое анализируемой языковой единицей суждение, еще раз обратимся к ее компонентному составу. Прилагательное красный, употребленное в краткой форме, может выражать не только значение '3. Устар. и нар.поэт. Красивый, прекрасный (обычно как постоянный эпитет)' (НБАС, т. 8, с. 592), но и значение ' 1 . Имеющий окраску одного из основных цветов радуги; цвета крови и его близких оттенков' (БАС, т. 5, стб. 1596). Конструкция противопоставления, лежащая в основе структурной модели анализируемой авторской паремии, изначально предполагает противопоставление разных предметов (дома, кровавые следы) по одному и тому же качественному признаку (красна), то есть Москва, которая не красна (красива) домами, должна быть красна (красива) кровавыми следами. Как видим, вторая часть данной конструкции по своему содержанию противоречит ценностной картине мира: кровавые следы независимо от причин их происхождения могут ассоциироваться лишь с болью и даже смертью (в основе данной ассоциативной связи лежит негативное отношение к объекту номинации, объективируемое семой логической негативной оценки, локализующейся в околоядерной части денотативного макрокомпонента значения слова кровавый).

Таким образом, анализируемая авторская паремия была создана на базе паремииисточника с использованием не только структурно-смысловой трансформации, но и языковой игры, состоящей в создании синтаксической единицы (словосочетание *красна кровавыми следами восстанавливается из содержания паремии), главное и зависимые слова которой имеют несовместимые значения. Намеренное объединение неизвестным авто- ром прилагательного красный, употребленного в краткой форме и выражающего положительную оценку (сема логической положительной оценки входит в околоядерную часть понятийного макрокомпонента значения прилагательного красный, а также понятийные семы 'красивый', 'прекрасный') и словосочетания кровавый след, в структуре значение которого выделяются как микрокомпонент отрицательной понятийной семантики, так и актуализированные негативные семы коннотативного блока значения (сема 'отрицательная оценка' оценочного компонента значения, семы 'неодобрение' и 'ужас' эмотивного компонента значения), привело к появлению сочетания слов, прямые смыслы которых вступают в противоречие друг с другом. В системе выразительных средств русского языка подобный прием принято называть катахрезой - «троп, тропеическое сочетание в одной синтагме двух или нескольких несовместимых, но не контрастных слов» (Энциклопедический словарь-справочник, с. 153).

Использование данного тропа обусловило значительную экспрессивность исследуемой авторской паремии.

Следует отметить, что рассмотренная языковая игра не ограничивается катахрезой. В восстановленном словосочетании красна кровавыми следами расположение рядом прилагательных красный (в краткой форме) и кровавый, несмотря на снятую многозначность (первая часть авторской паремии предложение Не красна Москва домами исключает двойственность понимания значения слова красный при его сочетании со второй частью паремии) и возможность употребления зависимых слов (кровавыми следами) только в творительном падеже (что обусловлено валентными свойствами лексемы красный в значении 'красивый, прекрасный'), создает предпосылки для восприятия слова красный в его основном значении ('имеющий окраску одного из основных цветов радуги; цвета крови и его близких оттенков'). Достоверность данного понимания подтверждают мотивирующий экстралингвистический контекст (Москва в действительности была не «красива кровавыми следами», а «красна от этих многочисленных следов») и аллитерация (симметричное повторение согласных $к p$ ). 
В итоге вариативность содержания авторской паремии Не красна Москва домами, а кровавыми следами, явившаяся следствием обыгрывания значения слова-компонента красный, способствовала усилению ее образного потенциала и воздействующей функции.

Основываясь на анализе мотивирующих внеязыковых факторов, а также учитывая использованные неизвестным автором приемы языковой игры, выражаемое анализируемой единицей языка суждение может быть сформулировано таким образом: 'Изза неоправданно жестоких действий регулярных армейских частей по подавлению декабрьского вооруженного восстания вся Москва была покрыта кровавыми следами'. Тип авторской паремии - пословичнопоговорочное выражение.

Авторская паремия Быль молодиу не укор, а Москва Дубасову не убыток (Стрелы, с. 8) образована на базе паремии-источника Быль молодиу не укор, выражающей следующее суждение: 'За грехи прошлого не упрекают' (Жуков, с. 54). Так как слово-компонент укор употреблено в своем основном значении ' 1 . Упрек, порицание; укоризна' (БАС, т. 16, стб. 470-471), паремия-прототип является пословично-поговорочным выражением.

Способ образования анализируемой языковой единицы - расширение компонентного состава паремии-источника путем добавления предложения а Москва Дубасову не убыток, построенного на базе такой же структурной модели (сущ. в форме им. п., ед. ч., жен. p. + сущ. в форме дат. п., ед. ч., муж. р. + отриц. частица не + сущ. в форме им. п., ед. ч., муж. р.), что и первая часть.

Отнесение рассматриваемой паремии к одной из четырех высших логико-семиотических инвариантных групп сопряжено с определенными сложностями, поскольку расширение компонентного состава исходной паремии посредством добавления полностью идентичного в структурном отношении, но отличающегося по компонентному составу предложения, по сути, обусловливает дублирование объективированной классической паремией типической ситуации. Обобщенный смысл паремии Быль молодиу не укор (а также добавленного неизвестным автором предложения $a$ Москва Дубасову не убыток) может быть передан следующим образом: 'Что-либо, выраженное словом-существительным, для лица мужского пола не является чем-либо, выраженным словом-существительным'. Как нам известно, все паремии (и классические, и трансформированные) построены на противопоставлении (иногда - сопоставлении) ключевых слов-компонентов. В рассматриваемой паремии противопоставленными оказываются, с одной стороны, «быль» (молодцу) и «Москва» (Дубасову), с другой - «не укор» и «не убыток». Иначе говоря, если есть быль (прошлое), то не будет укора (упреков за это прошлое) молодцу, так же как если есть Москва, то не будет убытка (ущерба, вреда) Дубасову (русскому военачальнику, адмиралу Ф.В. Дубасову, который в 1905-1906 гг. занимал пост московского генерал-губернатора). Согласно теории структурной паремиологии, пословицы, поговорки и пословично-поговорочные выражения, объективирующие типические ситуации, в которых «различные вещи, и прежде всего противоположные, враждебны друг другу и стремятся не быть вместе (наличие одной из вещей делает вероятным отсутствие другой)» [Пермяков, 1979, с. 119], входят в состав высшей логико-семиотической инвариантной группы I (2), в которой моделируются отношения между вещами [Пермяков, 1970, с. 20].

Таким образом, и паремия-источник, и образованная на ее основе новая языковая единица входят в состав одной и той же высшей логико-семиотической инвариантной группы. Объединяет две указанные языковые единицы также и то, что они обе входят в состав одной логико-тематической группы «Хорошее - плохое».

Так как в процессе образования анализируемой языковой единицы паремия-источник не была подвергнута каким-либо изменениям, ее узнавание в составе данной единицы не представляет никакого труда для носителей языка.

Рассмотрим компонентный состав анализируемой авторской паремии.

Существительное быль имеет значение '1. Устар. То, что уже прошло; прошлое, былое' (НБАС, т. 2, с. 287). Существительное молодещ определяется как ' 1 . Молодой человек в расцвете сил, крепкий и статный' (НБАС, т. 10, с. 338). Отрицательная частица 
не имеет следующее значение: '1. Вносит знач. полного отрицания того, что обозначает слово или словосочетание, перед которым оно стоит' (НБАС, т. 11, с. 498). Существительное укор имеет следующее толкование: '1. Упрек, порицание; укоризна' (БАС, т. 16, с. 470). Союз $a$ употреблен в сопоставительном значении и выражает следующее: '2. Присоединяет предложения или члены предложения, уточняющие, раскрывающие или дополняющие содержание ранее сказанного' (НБАС, т. 1, с. 59). Существительное Москва именует город, столицу России. Дубасов - фамилия русского военачальника. Существительное убыток имеет следующее значение: '2. Вред, ущерб, наносимый, причиняемый кому-, чему-либо' (БАС, т. 16, с. 86).

Сумма значений слов-компонентов авторской паремии Быль молодиу не укор, а Москва Дубасову не убыток может быть представлена следующим образом: 'Прошлое крепкого и статного молодого человека в расцвете сил не является ему упреком, так же, как Москва не наносит ущерба генералгубернатору Ф.В. Дубасову'. С большой долей вероятности можем предположить, что данная сумма значений слов-компонентов паремии не являет собой выражаемое ею суждение. Таким образом, перед нами либо пословица, либо пословично-поговорочное выражение.

Анализируемая авторская паремия обязана своим появлением прославившемуся жестокостью в подавлении вооруженного восстания в Москве в декабре 1905 г. русскому адмиралу, московскому генерал-губернатору Ф.В. Дубасову. Участники и очевидцы тех событий описывают в воспоминаниях ужас происходившего в Москве. Так, революционер, большевик и советский государственный деятель 3.Н. Доссер писал: «Около 7-ми часов утра (17 декабря 1905 года. $-A$. 3.) я проснулся от непрерывного хлопанья дверей, как мне показалось. Это началась бомбардировка пушками Пресни с трех сторон от Кудрина и Ваганьковского кладбища и гаубичной батареей из Дорогомилова. Горбатый мост обстреливался из пулемета. Были пулеметы и в других местах. Нападавшие сразу же развили интенсивный огонь, в минуту делалось до пяти орудийных выстрелов. Вся Пресня за- сыпалась свинцом и сталью. Окраинные дома загорались один за другим. $<$.. $>$ Они (войска. $A$. 3.) занимались поджогом уцелевших домов и беспощадным расстрелом всех, кто пытался найти себе спасение через реку Москву или переулки. Бомбардировка не стихала до самой ночи, светлой от зарева пожаров. Мы были окружены огненным кольцом в буквальном смысле слова» (Доссер, с. 19-20).

Как было отмечено ранее, точные сведения о количестве убитых и раненых в ходе вооруженного восстания в Москве в декабpe 1905 г. отсутствуют. Сторонники монархии старались представить действия войск в выгодном для себя свете. Так, один из видных монархистов А.А. Киреев в дневниковых записях от 26 декабря 1905 г. отмечал следующее: «Открытая революция подавлена в Москве, но потери людьми в рядах революции очень незначительны, убитых не много... Ведь войска действовали (как оказывается) очень мягко - разгоняя банды вместо того, чтобы их уничтожать» (Киреев, c. 120). Однако, если войсками были применены тяжелые дальнобойные артиллерийские орудия и пулеметы, число жертв должно было исчисляться тысячами, а может быть, и десятками тысяч.

Таким образом, суждение, выражаемое авторской паремией Быль молодиу не укор, а Москва Дубасову не убыток, может быть сформулировано следующим образом: 'В связи с тем, что Ф.В. Дубасов является приближенным императора Николая II и занимает высокий пост московского генерал-губернатора, никакого наказания за отданные им приказы по жестокому подавлению декабрьского вооруженного восстания в декабре 1905 г. в Москве он не понесет'. Тип авторской паремии - пословичнопоговорочное выражение.

\section{Выводы}

Декабрьское вооруженное восстание в Москве в 1905 г. было одним из самых резонансных событий в истории первой русской революции. Небывалая жестокость царской власти, проявленная при его подавлении, вызвала мощнейший всплеск негодования в российском обществе, способствовала усилению позиций левых и центристских партий, 
стала неоспоримым аргументом в пользу смены системы политического устройства страны.

Данное событие отразилось на системе русского языка. Неизвестные авторы общественно-политических сатирических журналов, стремясь акцентировать внимание читателей на ужасных последствиях использования регулярных частей армии Российской империи против граждан своей страны, создали новые паремии Не красна Москва домами, а кровавыли следами и Быль молодиу не укор, а Москва Дубасову не убыток на основе общеизвестных паремий Не красна изба углами, а красна пирогами и Быль молодиу не укор.

Проведенный анализ данных языковых единиц позволил установить паремии-источники трансформации, научно обосновать узнаваемость в авторских паремиях их паремийпрототипов, рассмотреть мотивирующее событие внешней среды, сформулировать выражаемые новыми единицами языка суждения, определить их типы. Авторская паремия Не красна Москва домами, а кровавыми следами и ее паремия-источник входят в состав высшей логико-семиотической инвариантной группы II (2) и логико-тематической группы «Красивый - уродливый». Авторская паремия Быль молодиу не укор, а Москва Дубасову не убыток вместе с паремией-источником относятся к высшей логико-семиотической инвариантной группе I (2) и логико-тематической группе «Хорошее - плохое». Общность отнесения рассмотренных единиц и их паремийисточников к одним и тем же высшим логикосемиотическим инвариантным группам и логико-тематическим группам в совокупности с общностью их структурных моделей обусловила узнаваемость в них классических паремий русского языка, послуживших основой для их образования.

На основе оценки событий декабрьского вооруженного восстания, произошедшего в Москве в 1905 г., которая была дана их современниками, сформулированы выражаемые рассмотренными единицами языка суждения. Авторская паремия Не красна Москва домами, а кровавыми следами выражает суждение 'Из-за неоправданно жестоких действий регулярных армейских частей по подавлению декабрьского вооруженного восстания вся
Москва была покрыта кровавыми следами'. Авторская паремия Быль молодиу не укор, а Москва Дубасову не убыток выражает суждение 'В связи с тем, что Ф.В. Дубасов является приближенным императора Николая II и занимает высокий пост московского генерал-губернатора, никакого наказания за отданные им приказы по жестокому подавлению декабрьского вооруженного восстания в декабре 1905 г. в Москве он не понесет'.

Наличие в обеих авторских паремиях первично маркированных слов-компонентов позволило определить их как пословичнопоговорочные выражения.

В качестве перспектив исследования можно отметить дальнейшее изучение авторской паремиологии русского языка периода 1905-1907 гг., систематизацию авторских паремий в зависимости от мотивировавших их образование событий общественно-политической жизни страны, создание словаря авторской паремиологии периода первой русской революции.

\section{СПИСОК ЛИТЕРАТУРЫ}

Антонова О. Н., 2011. Изменение компонентного состава как вид трансформации паремий (на материале англоязычных массмедиа) // Вестник Бурятского государственного университета. № 11. C. 3-5.

Батулина А. В., 2003. Пословично-поговорочные выражения в современном русском языке : дис. ... канд. филол. наук. Великий Новгород. 211 с.

Бегун В. В., 2010. Рекламный слоган как трансформация культурных стереотипов // Вестник Пермского университета. Российская и зарубежная филология. Вып. 1 (7). С. 31-37.

Буренкова С. В., 2008. Комизм псевдопословиц как способ переоценки витальных ценностей // Фундаментальная наука вузам. № 4. С. 80-86.

Бутько Ю. В., 2008. Ассоциативный контекст и его реализация в новых паремиях // Вестник Челябинского государственного педагогического университета. № 6. С. 142-153.

Вальтер Х., Мокиенко В. М., 2005. Антипословицы русского народа. СПб. : Нева. 576 с.

Гнедаш С. И., 2005. Провербиальные трансформанты в функциональном стиле прессы и публицистики (на материале немецкоязычной печати ФРГ) : автореф. дис. ... канд. филол. наук. M. 24 c. 
Демидкина Е. А., 2017. Репрезентация интеллектуальных качеств человека в немецких паремиях и антипословицах // Филологические науки. Вопросы теории и практики. № 1 (67), ч. 1. С. 91-94.

Дидковская В. Г., Петрова Л. А., 2014. Пословицы и поговорки как объект «наивной лингвистики» // Вестник Новгородского государственного университета им. Ярослава Мудрого. № 77. C. $68-70$.

Жигарина Е. Е., 2006. Современное бытование пословиц: вариативность и полифункциональность текстов : автореф. дис. ... канд. филол. наук. М. 24 с.

Загребельный А. В., 2013. Лексика общественнополитической сферы русского языка начала XX века в семасиологическом и функциональном аспектах. Вологда : ИСЭРТ РАН. 248 с.

Загребельный А. В., 2018. Авторская паремия Красному утру не верь! Хвались вечером утром несеченный в русском языке 1905-1907 годов // Ученые записки Новгородского государственного университета им. Ярослава Мудрого. № 6 (18). URL: https://www.novsu.ru/file/ 1484325 (дата обращения: 01.07.2019).

Загребельный А. В., 2019а. Методика диахронического анализа авторских паремий русского языка: возможности применения // Вестник Волгоградского государственного университета. Серия 2, Языкознание. Т. 18, № 1. С. 196-208. DOI: https://doi.org/10.15688/jvolsu2.2019.1.17.

Загребельный А. В., 2019б. Авторская паремия Старого воробья на овсе не поймаешь в русском языке начала XX века // Филологические науки. Научные доклады высшей школы. № 3. С. 13-20.

Зайкина 3. М., 2018. Понятийная и структурно-типологическая специфика паремиологических единиц // Филологические науки. Вопросы теории и практики. № 1 (79), ч. 1. С. 108-112.

Кирсанова М. А., 2014. Антипословицы с гендерным компонентом в современном английском языке // Наука и школа. № 1. С. 91-95.

Константинова А. А., 2009. Пословицы и поговорки в современной англо-американской пресce: авторское использование традиционных паремий // Вестник Томского государственного университета. № 322. С. 22-25.

Никитина Т. Г., 2014. Новый «статус» русских антипословиц // Вестник Новгородского государственного университета им. Ярослава Мудрого. № 77. С. 87-89.

Пермяков Г. Л., 1970. От поговорки до сказки. М. : Наука. 240 с.

Пермяков Г. Л., 1979. Пословицы и поговорки народов Востока. Систематизированное собра- ние изречений двухсот народов. М. : Наука. $671 \mathrm{c}$.

Пермяков Г. Л., 1988. Основы структурной паремиологии / сост., вступ. ст. Г. Л. Капчица. М. : Наука. 235 с.

Савенкова Л. Б., 2014. Представление о коллективном субъекте в пространстве современных русских антипословиц // Вестник Новгородского государственного университета. № 77. C. 35-37.

Соловьева Н. С., 2011. Социолингвистический портрет американцев и русских по материалам словарей антипословиц (сопоставительный анализ) // Проблемы истории, филологии, культуры. № 3. С. 231-235.

Сташкова М. А., 2015. Функционирование пословиц и антипословиц с гендерным компонентом в современном английском языке : автореф. дис. ... канд. филол. наук. М. 23 с.

Швыдкая Л. И., 2011. Лингвистический статус традиционных паремий и антипословиц (на материале русских и английских фразеографических источников) // Проблемы истории, филологии, культуры. № 3. С. 236-239.

\section{ИСТОЧНИКИ И СЛОВАРИ}

$Б A C$ - Словарь современного русского литературного языка. Т. 1-17. М. ; Л. : Изд-во Акад. наук CCCP, 1950-1965.

Доссер - Доссер 3. На Пресне и в Московском Комитете в декабрьские дни 1905 г. // Декабрь 1905 года на Красной Пресне : сб. ст. и воспоминаний / под ред. В. Невского ; Агитпропотдел Красно-Преснинск. Райкома Р. К. П. (б.). М. ; Пг. : Гос. изд-во, 1924. С. 9-20.

Жуков - Жуков В. П. Словарь русских пословиц и поговорок. 7-е изд., стер. М. : Рус. яз., 2000. $544 \mathrm{c}$.

Зарницьы-Зарницы. 1906. № 5.12 с.

Киреев - Киреев А. А. Дневник. 1905-1910 / сост. К. А. Соловьев. М. : Рос. полит. энцикл. (РОССПЭН), 2010. $472 \mathrm{c}$.

$M A C$ - Словарь русского языка. В 4 т. / АН СССР, Ин-т рус. яз. 3-е изд., стер. М. : Рус. яз., 19851988.

НБАС - Большой академический словарь русского языка / РАН. Ин-т лингвист. исслед. ; гл. ред. К. С. Горбачевич, А. С. Герд. Т. 1 - . М. ; СПб. : Наука, 2004-

Невский - Невский В. И. Советы и вооруженное восстание в 1905. М. : Всесоюз. о-во полит. каторжан и ссыльно-поселенцев, 1931. 429 с.

Революичи 1905 года - Революция 1905 года и самодержавие / Центрархив ; подгот. к печ. В. П. Се- 
менников ; предисл. А. М. Панкратовой ; примеч. сост. М. И. Ахун, В. А. Петров. М. ; Л. : Гос. изд-во, 1928.284 с.

СРП-Словарь русских пословиц : Около 1000 единиц / под ред. В. М. Мокиенко. М. : Астрель : АCT, 2007. $381 \mathrm{c}$.

Стенографический отчет - Стенографический отчет заседания 29 января 1906 года общего собрания членов «Союза 17 октября» // Партия «Союз 17 октября». Протоколы съездов, конференций и заседаний ЦК. В 2 т. Т. 1. Протоколы съездов и заседаний ЦК. 19051907 гг. М. : Рос. полит. энцикл. (РОССПЭН), 1996. C. 84-119.

Стрель-Стрелы. 1906. № 9. 12 с.

Тихомиров - Дневник Л.А. Тихомирова. 19051907 гг. / сост. А. В. Репников, Б. С. Котов ; [авт. предисл., коммент. и примеч. А. В. Репников]. М. : Полит. энцикл., 2015. 599 с.

Энииклопедический словарь-справочник - Энциклопедический словарь-справочник. Выразительные средства русского языка и речевые ошибки и недочеты / под ред. А. П. Сковородникова. 2-е изд. М. : Флинта : Наука, 2009. 480 с.

\section{REFERENCES}

Antonova O.N., 2011. Izmenenie komponentnogo sostava kak vid transformacii paremij (na materiale angloyazychnyh massmedia) [Change of component structure as a type of transformation of paremias (on material of English-language mass media)]. Vestnik Buryatskogo gosudarstvennogo universiteta [Bulletin of the Buryat state university], no. 11, pp. 3-5.

Batulina A.V., 2003. Poslovichno-pogovorochnye vyrazheniya $v$ sovremennom russkom yazyke: diss. ... kand. filol. nauk [Proverbial expressions in modern Russian. Cand. philol. sci. diss.]. Velikiy Novgorod. 211 p.

Begun V.V., 2010. Reklamnyj slogan kak transformaciya kul'turnyh stereotipov [Advertisings Slogans as Cultural Stereotypes Transformation]. Vestnik Permskogo universiteta. Rossiyskaya $i$ zarubezhnaya filologiya [Perm University Herald. Russian and Foreign Philology], iss. 1 (7), pp. 31-37.

Burenkova S.V., 2008. Komizm psevdoposlovic kak sposob pereocenki vital'nyh cennostej [Comedy of pseudo-proverbs as way of revaluation of vital values]. Fundamental'naja nauka vuzam [Fundamental Science to Higher Education Institutions], no. 4, pp. 80-86.

But'ko YU.V., 2008. Associativnyj kontekst i ego realizaciya $\mathrm{v}$ novyh paremiyah [Associative
Context and Its Realization in New Paremias]. Vestnik Chelyabinskogo gosudarstvennogo pedagogicheskogo universiteta [Herald of the Chelyabinsk State Pedagogical University], no. 6, pp. 142-153.

Val'ter H., Mokienko V.M., 2005. Antiposlovicy russkogo naroda. [Anti-proverbs of the Russian People]. Saint- Petersburg, Neva Publ. 576 p.

Gnedash S.I., 2005. Proverbial'nye transformanty $v$ funkcional'nom stile pressy i publicistiki (na materiale nemeckoyazychnoj pechati FRG): avtoref. diss. ... kand. filol. nauk. [Proverbialny Transformants in Functional Style of the Press and Journalism (on Material of the GermanSpeaking Press of Germany). Cand. philol. sci. abs. diss]. Moscow. 24 p.

Demidkina E.A., 2017. Reprezentaciya intellektual'nyh kachestv cheloveka v nemeckih paremiyah i antiposlovicah [Representation of Person's Intelligent Qualities in the German Proverbs and Antiproverbs]. Filologicheskie nauki. Voprosy teorii i praktiki [Philological Sciences. Issues of Theory and Practice], no. 1 (67), part 1, pp. 91-94.

Didkovskaya V.G., Petrova, L.A., 2014. Poslovicy i pogovorki kak ob"ekt «naivnoj lingvistiki» [Proverbs and Sayings as an Object of "Naive Linguistics"]. Vestnik Novgorodskogo gosudarstvennogo universiteta im. Yaroslava Mudrogo [Vestnik of Yaroslav the Wise Novgorod State University], no. 77, pp. 68-70.

Zhigarina E.E., 2006. Sovremennoe bytovanie poslovic: variativnost' $i$ polifunkcional'nost' tekstov: avtoref. diss. ... kand. filol. nauk [Modern existence of Proverbs: variability and polyfunctionality of texts: author's abstract. Cand. philol. sci. abs. diss.]. Moscow. 24 p.

Zagrebelnyy A.V., 2013. Leksika obshchestvennopoliticheskoj sfery russkogo yazyka nachala $X X$ veka $v$ semasiologicheskom $i$ funkcional'nom aspektah [Lexicon of the Social and Political Sphere of the Russian Language of the Beginning of the 20th Century in Semasiological and Functional Aspects]. Vologda, ISEDT RAS Publ. 248 p.

Zagrebel'nyy A.V., 2018. Avtorskaya paremiya Krasnomu utru ne ver'! Hvalis' vecherom utrom nesechennyj v russkom yazyke 1905 1907 godov [Author's Paroimia Do not Trust Good Morning! Praise Yourself in the Evening if You Have not Been Flogged in the Morning in the Russian Language of the 1905 - 1907]. Uchenye zapiski Novgorodskogo gosudarstvennogo universiteta ime. Jaroslava Mudrogo [Research notes the Yaroslav the Wise Novgorod State University], no. 6 (18). URL: https://www.novsu.ru/file/1484325. 
Zagrebel'nyy A.V., 2019a. Metodika diahronicheskogo analiza avtorskih paremij russkogo yazyka: vozmozhnosti primeneniya [Methods of the diachronic analysis of author's proverbs of the Russian language: the possibility of application]. Vestnik Volgogradskogo gosudarstvennogo universiteta. Serija 2. Jazykoznanie [Science Journal of VolSU. Linguistics], vol. 18, no. 1,pp. 196-208. DOI: https://doi.org/10.15688/jvolsu2.2019.1.17.

Zagrebel'nyy A.V., 2019b. Avtorskaya paremiya Starogo vorob'ya na ovse ne pojmaesh' v russkom yazyke nachala XX veka [The author's paroimia You can not catch an old sparrow with oat in the Russian Language of the beginning of the 20th century]. Filologicheskie nauki. Nauchnye doklady vysshej shkoly [Philological Sciences. Scientific Essays of Higher Education], no. 3, pp. 13-20.

Zaykina Z.M., 2018. Ponyatijnaya i strukturnotipologicheskaya specifika paremiologicheskih edinic [Conceptual and Structural-Typological Pecularities of Paremiological Units]. Filologicheskie nauki. Voprosy teorii i praktiki [Philological Sciences. Issues of Theory and Practice], no. 1 (79), part 1, pp. 108-112.

Kirsanova M.A., 2014. Antiposlovicy s gendernym komponentom $\mathrm{v}$ sovremennom anglijskom yazyke ]Anti-Proverbs with Gender Component in the Modern English Language]. Nauka $i$ shkola [Science and School], no. 1, pp. 91-95.

Konstantinova A.A., 2009. Poslovicy i pogovorki v sovremennoj anglo-amerikanskoj presse: avtorskoe ispol'zovanie tradicionnyh paremij [Proverbs and Sayings in the Modern England and American Press: Author's Use of Traditional Paremias]. Vestnik Tomskogo gosudarstvennogo universiteta [Tomsk State University Journal], no. 322 , pp. $22-25$.

Nikitina T.G., 2014. Novyj «status» russkih antiposlovic [New "status" of the Russian anti-proverbs]. Vestnik Novgorodskogo gosudarstvennogo universiteta im. Jaroslava Mudrogo [Bulletin of the Novgorod State University of Yaroslav the Wise], no. 77, pp. 87-89.

Permyakov G.L., 1970. Ot pogovorki do skazki [From a saying to the fairy tale]. Moscow, Nauka Publ. $240 \mathrm{p}$.

Permyakov G.L., 1979. Poslovicy i pogovorki narodov Vostoka. Sistematizirovannoe sobranie izrechenij dvuhsot narodov [Proverbs and sayings of the people of the East. The systematized meeting of sayings of two hundred people], Moscow, Nauka Publ. 671 p.

Permyakov G.L., 1988. Osnovy strukturnoj paremiologii [Fundamentals of Structural Paremiology]. Moscow, Nauka Publ. 235 p.
Savenkova L.B., 2014. Predstavlenie o kollektivnom sub"ekte v prostranstve sovremennyh russkih antiposlovic [Idea of the collective subject in space of modern Russian anti-proverbs]. Vestnik Novgorodskogo gosudarstvennogo universiteta [Messenger of the Novgorod state university], no. 77 , pp. 35-37.

Solov'eva N.S., 2011. Sociolingvisticheskij portret amerikancev i russkih po materialam slovarej antiposlovic (sopostavitel'nyj analiz) [Sotsiolingvistichesky a portrait of Americans and Russians on materials of dictionaries of antiproverbs (the comparative analysis)]. Problemy istorii, filologii, kul'tury [Problems of history, philology, culture], no. 3, pp. 231-235.

Stashkova M.A., 2015. Funkcionirovanie poslovic $i$ antiposlovic $s$ gendernym komponentom $v$ sovremennom anglijskom yazyke: avtoref. diss. ... kand. filol. nauk [Functioning of proverbs and anti-proverbs with a gender component in modern English: Cand. philol. sci. abs. diss.], Moscow. 23 p.

Shvydkaya L.I., 2011. Lingvisticheskij status tradicionnyh paremij i antiposlovic (na materiale russkih i anglijskih frazeograficheskih istochnikov) [The linguistic status of traditional paremias and anti-proverbs (on material of the Russian and English frazeografichesky sources)]. Problemy istorii, filologii, kul'tury [Problems of history, philology, culture]. no. 3, pp. 236-239.

\section{SOURCES AND DICTIONARIES}

Slovar' sovremennogo russkogo literaturnogo yazyka. T. 1-17. [Dictionary of the modern Russian literary language. Vol. 1-17], Moscow, Leningrad, Academy of Sciences of the USSR, 1950-1965.

Dossjer Z., 1924. Na Presne i v Moskovskom Komitete $v$ dekabr'skie dni $1905 \mathrm{~g}$. [On Presnya and in the Moscow Committee in December days 1905]. Dekabr' 1905 goda na Krasnoj Presne: sbornik statej i vospominanij / pod red. V. Nevskogo, Agitpropotdel Krasno-Presninsk. Rajkoma R. K. P. (b.) [December, 1905 on Krasnaya Presnya: the collection of articles and memoirs / under the editorship of V. Nevsky, Agitpropotdel Red Presninsk district committee. R.K. P. (b.)]. Moscow; Petersburg, State. publishing house, pp. 9-20.

Zhukov V.P., 2000. Slovar' russkih poslovic $i$ pogovorok [Dictionary of the Russian proverbs and sayings], Moscow, Russian Language, $544 \mathrm{p}$.

Zarnicy [Summer lightnings], 1906, no. 5, 12 p. 


\section{РАЗВИТИЕ И ФУНКЦИОНИРОВАНИЕ РУССКОГО ЯЗЫКА}

Kireev A.A., 2010. Dnevnik. 1905 - 1910 / sost. K.A. Solov'ev [Diary. 1905 - 1910]. Moscow, Russian political encyclopedia (ROSSPEN), 472 pp.

Slovar' russkogo jazyka. V4t. AN SSSR, In-t rus. jaz. 3-e izd., ster. [Dictionary of Russian. In $4 \mathrm{t}$. Academy of Sciences of the USSR]. Moscow, Russian language publ. house, 1985-1988.

Nevskij V.I., 1931. Sovety $i$ vooruzhennoe vosstanie v 1905 godu [Councils and an armed revolt in 1905]. Moscow: All-Union society of political convicts and exiled of settlers publ. house, $429 \mathrm{pp}$.

Bol'shoj akademicheskij slovar' russkogo yazyka. T. 1- [Big Academy dictionary of Russian. Vol. 1-], Moscow, Science Publ., 2004 - .

Revoljucija 1905 goda i samoderzhavie. Centrarhiv ; podgot. $k$ pech. V.P. Semennikov; predisl. A.M. Pankratovoj ; primech. sost. M.I. Ahun $i$ V.A. Petrov [Revolution of 1905 and autocracy. Centrarkhiv; preparation for printing V.P. Semennikov; A.M. Pankratova's preface; the note is made M.I. Akhun and V.A. Petrov]. Moscow; Leningrad: State publishing house, 1928, $284 \mathrm{pp}$.

Slovar' russkih poslovic: okolo 1000 edinic. V.M. Mokienko, Ju.A. Ermolaeva, A.A. Zajnul'dinovi dr.; pod red. V.M. Mokienko [Dictionary of the Russian proverbs: about 1000 units/V.M. Mokiyenko, Yu.A. Yermolaeva, A.A. Zaynuldinov, etc.; under the editorship of
V.M. Mokiyenko]. Moscow, Astrel Publ., AST Publ., 2007, 381 pp.

Stenograficheskij otchet zasedanija 29 janvarja 1906 goda obshhego sobranija chlenov «Sojuza 17 oktjabrja» [Verbatim record of a meeting on January 29, 1906 general meeting of members "Union on October 17"]. Partija «Sojuz 17 oktjabrja». Protokoly sezdov, konferencij $i$ zasedanij CK. V2-h tomah. T. 1. Protokoly sezdov i zasedanij CK. 1905 - 1907 gg. [Batch "Union on October 17”. Protocols of congresses, conferences and meetings of the Central Committee. In 2 volumes. Vol. 1. Protocols of congresses and meetings of the Central Committee. 1905 - 1907]. Moscow, Russian political encyclopedia (ROSSPEN) Publ., 1996, pp. 84-119.

Strely [Arrows], 1906, № 9, 12 pp.

Dnevnik L.A. Tihomirova. 1905 - 1907 gg. Sost. A.V. Repnikov, B.S. Kotov [L.A. Tikhomirov's diary. 1905 - 1907. Originators A.V. Repnikov, B.S. Kotov]. Moscow, Political encyclopedia Publ., 2015, 599 pp.

Jenciklopedicheskij slovar'-spravochnik. Vyrazitel'nye sredstva russkogo jazyka $i$ rechevye oshibki $i$ nedochety. Pod red. A.P. Skovorodnikova [Encyclopedic dictionary reference. Means of expression of Russian and speech mistakes and defects. Under the editorship of A.P. Skovorodnikov]. Moscow, Flint Publ., Science Publ., 2009, 480 pp.

\section{Information About the Author}

Artur V. Zagrebelnyy, Candidate of Sciences (Philology), Researcher, Department of Editorialand-Publishing Activity and Science-Information Support, Vologda Research Center of the Russian Academy of Sciences, Gorkogo St, 56a, 160014 Vologda, Russia, pechorin2106@mail.ru, https://orcid.org/0000-0002-4573-4222

\section{Информация об авторе}

Артур Владимирович Загребельный, кандидат филологических наук, научный сотрудник отдела редакционно-издательской деятельности и научно-информационного обеспечения, Вологодский научный центр РАН, ул. Горького, 56a, 160014 г. Вологда, Россия, pechorin2106@mail.ru, https://orcid.org/0000-0002-4573-4222 